\title{
PELATIHAN ATLETIK DASAR BAGI GURU-GURU PENDIDIKAN JASMANI SEKOLAH DASAR DESA EMPAT BALAI KECAMATAN KUOK
}

\author{
Raffly Henjilito ${ }^{1}$, Rices Jatra ${ }^{2}$, Dupri ${ }^{3}$, Zulkifli ${ }^{4}$, Rizki Aridho ${ }^{5}$ \\ Program Studi Pendidikan JasmanikesrekUniversitasIslam Riau ${ }^{1,2,3,4,5}$ \\ rafflyhenjilito@edu.uir.ac.id ${ }^{1}$,ricesjatra@edu.uir.ac.id ${ }^{2}$,dupri@edu.uir.ac.id ${ }^{3}$, \\ zulkifli.darwis@edu.uir.ac.id ${ }^{4}$, Rizkiaridho123@gmail.com ${ }^{5}$
}

Pelatihan atletik dasar merupakan salah satu upaya untuk menyebarluaskan cara mengajar atletik bagi para guru-guru Pendidikan Jasmani sekolah dasar yang selama ini sudah mengajar tetapi dengan menggunakan cara pendekatan ke arah prestasi. Sehingga para siswa cenderung kurang tertarik dan materinya sangat terbatas, kegiatan ini juga merupakan salah satu usaha memperkaya bahan pembelajaran yang disajikan dalam bentuk modifikasi yang dimana tampilannya dalam model yangbervariasi. Kegiatan pengabdian Kepada Masyarakat yang dilaksanakan di Desa Empat Balai Kecematan Kuok, antusias para guru yang mengikuti pelatihan atletik dasar bagi guru Sekolah Dasar se Desa Empat Balai, Kecamatan Kuok sangat tinggi hal ini di karenakan belum adanya pelatihan atletik dasar khusus untuk guru sekolah dasar. Manfaat utama kegiatan ini adalah guru memahami mengenai pelatiahn atletik dasar sehingga nantinya bisa diterapkan ditengah - tengah pembelajaran olahraga disekolah.Kegiatan pengabdian ini juga memberikan suatu pengetahuan dan pemahanan tentang olahraga yang sangat disukai oleh siswa.

Kata kunci:Atletik Dasar, Guru Pendidikan Jasmani, Sekolah Dasar

\section{Basic Athletic Training for Elementary School Physical Education Teachers in Empat Balai Village, Kuok District}

Basic athletic training is an effort to disseminate athletic teaching methods for elementary school Physical Education teachers who have been teaching, but by using an approach to achievement. So that students tend to be less interested and the material is very limited, this activity is also an effort to enrich the learning material presented in a modified form where it appears in a variety of models. The community service activities carried out in the village of Empat Balai, Kuok district, the enthusiasm of the teachers who took part in basic athletic training for elementary school teachers in Empat Balai Village, Kuok District was very high because there was no special basic athletic training for elementary school teachers. The main benefit of this activity is that the teacher understands basic athletic training so that later it can be applied in the middle of learning sports at school. This service activity also provides a knowledge and understanding of sports that are very liked by students.

Keywords: Basic Athletics, Physical Education Teacher, Elementary School 


\section{W/AHANA DEDIKASI \\ Artikel disetujui tanggal:28-05-2021 \\ Corresponden Author:Raffly Henjilito e-mail: rafflyhenjilito@edu.uir.ac.id \\ DOI: http://dx.doi.org/10.31851/dedikasi.v4i1.5507do}

PENDAHULUAN

Berdasarkan perkembangan

dunia pendidikan bahwa perguruantinggi ikut serta menyelenggarakan pengabdian pada masyarakat sesuai dengan sifat pengetahuan dan tujuan pendidikan tinggi (Hera, et al. 2018). Sehingga dari perguruan tinggi melakukan pengabdian ke guru-guru pendidikan jasmani sekolah dasar. Guru pendidikan jasmani di sekolah dasar adalah orang yang bertanggung jawab terhadap keberhasilan pertumbuhan dan perkembangan anak ditinjau dari aspek pola gerak dasar. Oleh karena itu pengetahuan maupun keterampilan dalam mengajarkan aspek-aspek gerak dasar harus dimiliki oleh guru pendidikan jasmani di sekolah dasar.

Dilihat dari latar belakang pendidikan, para guru pendidikan jasmani di Desa Empat Balai, Kecamatan Kuok sangat beragam, ada yang lulusan SGO, D2 PGSD, ada yang S-1 bahkan ada yang sama sekali tidak berlatar belakang olahraga. Keragaman latar belakang pendidikan ini mungkin sangat berpengaruh terhadap penguasaan konsep pembelajaran Pendidikan Jasmani di SD terutama pembelajaran atletik. Kemauan guru untuk melakukan belajar mandiri baik lewat internet, buku, majalah atau media elektronik, juga akan berpengaruh terhadap daya inovasi guru dalam mengajar.

Di Desa Empat Balai, Kecamatan Kuok, seorang guru Pendidikan Jasmani mengajar pada level kelas bawah (kelas 1-3) dan juga mengajar kelas atas (kelas IV-VI). Bahkan tidak sedikit seorang guru harus mengajar di dua sekolah dasar yang berdekatan.Kondisi semacarn ini menuntut seorang, guru Pendidikan Jasmani harus rajin membuat program-program pembelajaran yang sesuai dengan perumbuhan dan perkembangan anak. Minimnya buku ajar yang tersedia di sekolah membuat guru harus mencari bahan-bahan dari sumber lain yang ada. Dengan demikian untuk memperkaya 


\section{W/AHANA DEDIKASI}

pengetahuan guru, maka kegiatan seperti inservis training, seminar, atau pelatihan bagi guru harus selalu diselenggarakan.

Atletik

Atletik merupakan salah satu cabang olahraga yang tertua, yang telah dilakukan oleh manusia sejak zaman purba sampai dewasa ini (Risma et al, 2021). Bahkan boleh dikatakan sejak adanya manusia di muka bumi ini atletik sudah ada, karena gerakan-gerakan yang terdapat dalam cabang olahraga atletik, seperti berjalan, berlari, melompat, dan melempar adalah gerakan yang dilakukan oleh manusia di dalam kehidupannya sehari-hari.Pada dasarnya hampir dari semua cabang olahraga yang bersifat permainan mengandung unsur-unsur atletik seperti, berlari, menolak, melompat dan lain sebagainya.Oleh karena itu, tidak berlebihan kiranya jika dikatakan bahwa atletik adalah induk dari semua cabang olahraga.

Cabang olahraga atletik terdiri dari beberapa nomor yaitu jalan, lari lompat dan lempar.Lari terdiri dari lari jarak pendek, lari jarak menengah, lari jarak jauh dan marathon. Lari jarak pendek memiliki nomor lari diantaranya lari 50 meter, lari 100 meter, lari 200 meter dan lari 400 meter. Lompat terdiri dari lompat jauh, lompat jangkit, lompat tinggi dan lompat tinggi gala (Awali,2020).

$$
\text { Perkembangan prestasi }
$$

olahraga merupakan akumulasi dari kualitas fisik, tehnik, taktik dan kematangan psikis olahragawan yang disiapkan secara sistematis melalui proses pembinaan yang benar. Keberhasilan pencapaian prestasi olahraga; ditentukan oleh berbagai faktor satu diantaranya adalah penjenjangan latihan sesuai dengan tingkat usia anak Penjejangan latihan ada empat tahap berdasarkan usia yakni : Learn Basic Skill, Variety of Skill, Specific Training, High IntensityTraining.

Tahap learn basic skill merupakan tahap dasar untuk membangun pondasi keterampilan olahragawan, sehingga tahap ini perlu mendapatkan perhatian yang sungguh-sungguh. Implementasi learn 


\section{WAHANA DEDIKASI}

basic skill yang merupakan populasi luas adalah di Sekolah Dasar. Siswa Sekolah Dasar memiliki keterbatasanketerbatasan dalam mengadaptasi lingkungannya.Namun demikian bukan berarti anak-anak tidak dapat diberikan latihan gerak atau olahraga. Masa kanak-kanak merupakan masa yang paling aktif secara fisik dalam pertunbuhan manusia.Mereka sangat unik karena setiap tahap pertumbuhan dan perkembangan mengalami perubahan fisik dan mental yang besar.

Konsep pembinaan pada level dasar yang pertama perlu dilakukan adalah membawa anak mau melakukan dan mengialanainya secara terns menerus sesuai dengan program yang direncanakan. Untuk menjalankan program tersebut diperlukan variasi yang menyenangkan dan membuat anak memhutuhkan sekah gus mencapai sasaran. Bagi anak bermain merupakan dunianya, bermain adalah seluruh aktivitas anak temasuk bekerja, kesenangannya, dan merupakan media mengenal alam lingkungannya. Bermain termasuk aktivitas jasmani tidak sekedar mengisi waktu, tetapi merupakan kebutuhan anak seperti halnya makan maupun perawatan. Anak memerlukan variasi permainan untuk kesehatan fisik, mental maupun emosinya.

Beberapa materi yang dapat dipertimbangkan sebagai kurikulum gerakan dasar olahraga terutama dalam atletik adalah berbentuk berjalan.berlari, melompat, dan melempar: Permasalahaanya adalah apakah guru Pendidikan Jasmani di sekolah dasar telah menjalankan konsep pembelajaran atau konep pembinaan yang henar. Belajar gerak atletik tidak sekedar bagaimana melatih berlari. lompat, atau melempar yang dikemas dalam bentuk aktivitas menggunakan alai yang sebenamya, tetapi pembelajaran dalam bentuk games jauh akan lebih dapat merangsang kebutuhan gerak anak, karena disamping dapat melatih gerak dasar, juga dapat membawa anak ke situasi yang rnenyenangkan. Disisi lain game atletik dapat 


\section{W/AHANA DEDIKASI}

menggunakan peralatan yang lebih sederhana, tidak harus dengan peralatan standarkompetisi.

Pada tahap siswa sekolah dasar hal yang paling penting dalam menyajikan gerakan-gerakan dasar olahraga pada anak adalah menyesuaikan kemampuan anak dengan tehnik gerakan, peralatan dan aturan-aturan yang diigunakan serta dengan variasi yana menyenangkan. Tehnik gerakan berarti bahwa anak tidak dituntut untuk melakukan gerakan tehnik seperti pada olahraga sesungguhnya, tetapi yang penting adalah pada aspek dasar biomekanik yangsimpel.

Latihan secara teratur dan terprogram yang dilakukan sejak usia dini akan membuat teknik dasar berlari lebih baik (Sugarwanto, \& Okilanda., 2020). Latihan yang dilakukan tentunya tidak hanya teknik berlari akan tetapi juga teknik-teknik yang lain, sekaligus latihan taktik dan latihan flisik. Latihan yang dilakukan secara bervariasi akan membuat suasana latihan yang tidak membosankan sehingga menimbulkan minat untuk rajin mempraktekkan gerakanberlari.

Dengan kesepahaman bahwa standar mutu pendidikan jasmani harus selalu ditingkatkan, maka pelatihan atletik dasar bagi guru Pendidikan Jasrnani di Sekolah Dasar penting untuk dilakukan, guna membenahi konsep pembelajaran atletik yang belum mencapai sasaran.

\section{BAHAN DAN METODE}

Tempat pelaksanaan kegiatan pengabdian kepada Guru-Guru Pendidikan Jasmani Sekolah Dasar Desa Empat Balai Kecamatan Kuok, yang akan dilaksanakan pada Tanggal 27 Maret 2021

Metode Pelaksanaan

Metode Ceramah

Metode ini dilakukan pada saat tim memberikan penjelasan tentang bagaimana konsep pertumbuhan dan perkembangan anak dan bagaimana kemampuan guruguru Sekolah Dasar dalarn pembelajaran atau melatih Atletik dasar. 


\section{W/AHANA DEDIKASI}

Metode Praktik dan kelompok kecil

Metode praktik dan kelompok

kecil merupakan proses pelatihan yang disiapkan oleh instruktur untuk Guru-Guru Pendidikan Jasmani Sekolah Dasar Desa Empat Balai Kecamatan Kuok dengan tujuan memberikan kemudahan dalam pembelajaran dan melatih atletik dasar. Metode praktik dan kelompok kecil ini juga membantu setiap GuruGuru Pendidikan Jasmani Sekolah Dasar untuk lebih aktif dan mudah melakukan tehnik - tehnik dasar pada materi atletik. Metode tatap muka bertujuan memberikanpemahaman teori kepelatihanolahraga kepada para pelatih yangkemudian dilanjutkan dengan metodepraktik (Junaidi, et al., 2018).

Metode praktik langsung bertujuan mengaplikasikan bentuk, tahapan latihan di masing-masing cabang olahraga, sehingga azas ketepatan dalam mengaplikasikan teori tepat sasaran. Selanjutnya evaluasi dilakukan setelah seluruh pelatih mendapatkan materi praktik dan teori. (Okilanda, et. A1., 2021)
Metode Tanya Jawab

Metode ini sangat penting untuk menerima umpan balik antara tim instruktur dengan peserta bagaimana cara melakukan tehnik tehnik dasar atletik yang benar dan bias melakukannya.

\section{HASIL DAN PEMBAHASAN}

Pelaksanaan Tindakan

Pengabdian masyarakat merupakan tugas wajib yang harus dilaksanakan oleh setiap dosen, pelaksanaan tugas wajib ini dimanfaatkan oleh dosen Pendidikan Jasmanikesrek Universitas Islam Riau dengan memberikan pelatihan atletik dasar kepada guru - guru sekolah dasar se desa empat balai kecematan kuok. Pelaksanaan kegiatan pengabdian masyarakat ini berlangsung di sekolah SD 001 Empat Balai Kecematan Kuok selama satu hari, pada tanggal 27 Maret 2021.

Dalam sambutan Kepala Desa Empat Balai dan Kepala sekolah SD 001 Empat Balai, mengucapakan selamat datang kepada Dosen Pendidikan Jasmanikesrek 


\section{WAHANA DEDIKASI}

Universitas Islam Riau (UIR) yang lompat, lempar dan tolak. Dan juga telah memilih SD 001 Empat Balai permainan atletik akan memberi sebagai tempat untuk melakukan pengabdian masyrakat, kami harap anak-anak kesempatan melalui guru atletik untuk memanfaatkan latihan kedepannya sekolah kami selalu atletik yang bermanfaat, baik dalam menjadi tempat pilihan dari bapakbapak dan sekaligus dapat memotivasi siswa kami. hal kesehatan, pendidikan dan pemenuhan pencapain diri.

Untuk praktek pelatihan Adapun tujuan dari pelatihan atletik dasar secara langsung atletik dasar ini adalah guru olahraga dapat memahami bahwa banyak anak dilakukan di sekolah SD 001 Empat Balai, dosen Pendidikan Jasmanikesrek ini memanfaatkan ruangan sekolah yang membentuk persegi panjang, pelatihan atletik dasar ini sangat bermanfaat untuk guru-guru sekolah dasar yang ada di kecematan kuok.

\section{Hasil Kegiatan}

Pelaksanaan pada saat kegiatan berlangsung dengan menarik dan lancar.Sasaran pelatihan ini adalah guru - guru sekolah dasar yang ada dikecepatan kuok.Dengan adanya pelatihan ini dapat membawa kegembiraan dalam bermain atletik, guru sekolah dasar akan memperoleh gerakan inovatif terutama pada nomor atletik baik pada nomor jalan, lari, aktif dalam waktu yang sama, variasi dan bentuk dalam gerakan atletik merupakan gerakan alami, bahwa karakter petualangan yang ditanamkan dalam program menawarkan program pendekatan atletik yang cocok untuk anak-anak, bahwa struktur dan penilaian pertandinagn mudah, berdasarkan urutan peningkatan tim.

\section{KESIMPULAN}

Kegiatan pengabdian Kepada Masyarakat yang dilaksanakan di Desa Empat Balai Kecematan Kuok, antusias para guru yang mengikuti pelatihan atletik dasar bagi guru Sekolah Dasar se Desa Empat Balai, Kecamatan Kuok sangat tinggi hal ini di karenakan belum adanya pelatihan 


\section{WAHANA DEDIKASI}

atletik dasar khusus untuk guru sekolah dasar. Manfaat utama kegiatan ini adalah guru memahami mengenai pelatihan atletik dasar sehingga nantinya bisa diterapkan ditengah-tengah pembelajaran olahraga disekolah.

Kegiatan pengabdian ini juga memberikan suatu pengetahuan dan pemahanan tentang olahraga yang sangat disukai oleh siswa.Bagi peserta yang mengikuti kegiatan ini mempunyai antusias yang luar biasa di karenakan pelatihan atletik dasar ini merupakan pelatihan yang pertama kali dilaksanakan di tingkat sekolah dasar, khususnya disekolah dasar 001 Empat Balai Kecematan dan diharapkan kegiatan seperti ini dapat dilakukan setiap tahunnya di kabupaten yang berbeda.

\section{DAFTAR PUSTAKA}

Adang Suherman, (2002). Pendidikan Kebugaran Jasmani Sepanjang Hayat. Bandung: UPI Bandung.

Awali, M. (2020). Pengaruh Latihan Standing Broad Jump Terhadap Lompat Jauh Gaya Jongkok Siswa Smp Negeri 2
Lahat. Halaman Olahraga Nusantara (Jurnal Ilmu Keolahragaan), 3(2), $\quad$ 188198.

IAAF Kids Athletics (Atletik Bocah - IAAF). Alih Bahasa oleh H. Suvono Ds. Jakarta: Staf Set-IAAF RDC. (2002)

Hera, T., Rochayati, R., Diah, N., Elvandari, E., \& Nurdin, N. (2018). Pelatihan tari lenggang patah sembilan dalam konteks pementasan tari pada siswa-siswi smp negeri 30 kota palembang. Wahana dedikasi, 1(2).

Junaidi, I. A., Nasrullah, N., Imansyah, F., Bayu, I. M. A., Manullang, J. G., Handayani, W., \& Asriansyah, A. (2018).Pelatihan pencegahan dan perawatan cidera dalam berolahraga.Wahana dedikasi, 1(2).

Okilanda, A., Iswana, B., \& Wanto, S. (2021). PELATIHAN PELATIH FISIK LEVEL I NASIONAL OKU. Wahana Dedikasi: Jurnal PkM Ilmu Kependidikan, 3(2), 13-19.

Risma, N., Kamarudin, K., \& Henjilito, R. (2021). Construction Of 100 Meters Short Distance Test In Penjaskesrek Students FKIP Islamic University Of Riau. Halaman Olahraga 


\section{WAHANA DEDIKASI}

Nusantara (Jurnal Ilmu

Keolahragaan), 4(2).

Sugarwanto, S., \& Okilanda, A.

(2020). Pengaruh Latihan

Single Leg Hops Terhadap

Hasil Lompat Jangkit Siswa

Smp $\quad 1 \quad$ Sungai

Lilin. Kinestetik: Jurnal

Ilmiah Pendidikan

Jasmani, 4(1), 85-89. 